\title{
10
}

\section{The G20 and Climate Finance}

\author{
Introducing Finance Ministries to the Topic
}

The November 2009 St Andrews meeting of G20 Finance Ministers and Central Bank Governors was supposed to provide key input on climate finance. At this time, climate finance was a hot topic in the climate talks going into the Fifteenth Conference of the Parties to the United Nations Framework Convention on Climate Change (COP15), and observers expected it be an issue where the G20 could provide crucial input (author's observation as a government official working in the COP15 team of the Danish Ministry of Finance). Yet, the attempts to agree on a set of far-reaching conclusions at St Andrews largely failed, and since then this issue has mainly been addressed at the expert level. Thus, climate finance is similar to fossil fuel subsidies as a topic that G20 started addressing in 2009 at the ministerial level, followed by expert discussion. Yet, G20 output on climate finance in general has not had the same catalytic effect as the Pittsburgh commitment on fossil fuel subsidy reform. Nonetheless, it has had repercussions beyond the G20, especially among international institutions. How economisation played out in the case of the G20 addressing climate finance is the topic of this chapter. The chapter starts with an overview of G20 output, from the attempt to reach an agreement in 2009 to the more technical working groups that have addressed climate change from an economic perspective, followed by an analysis of the causes (entrepreneurship from Presidencies, membership circles, interaction with the United Nations Framework Convention on Climate Change [UNFCCC]) that shaped the output. Finally, the chapter discusses the consequences of this output at the international level (salient mainly regarding the UNFCCC and institutions tasked with providing analysis to the G20) and the domestic level (less discernible).

\subsection{Output: Failure to Commit, Followed by Knowledge Production}

In the spring of 2009, the UK Presidency played an active role in establishing an expert group on climate finance, with the purpose of delivering a report and the 
basis for a G20 finance ministers' and central bank governors "1 statement outlining their position before COP15. This statement was intended as a formal output of the November 2009 G20 meeting of Finance Ministers and Central Bank Governors in St Andrews (the United Kingdom). Thus, an important objective of the expert group was to influence the UNFCCC output. In the UNFCCC negotiations leading to COP15, it had become evident that climate finance commitments would be an important part of an agreement, but also that the negotiators from Annex II countries could not make credible commitments before they had been given the green light from their finance ministries. Several actors thought that the best way to avoid finance ministries vetoing or weakening climate finance commitments was to involve them in the negotiations and thus ensure that they felt a sense of ownership for the agreement and that the agreement reflected their views (Interview with senior European Commission official, 28 June 2011). Interestingly, climate change was outsourced from the UNFCCC negotiations not because it was uncontroversial (as Zelli, 2011 argues has been the case with the topic of reducing emissions from deforestation), but precisely because it was controversial.

In terms of informal output, the expert group sought to establish common ground through writing papers on topics such as public finance, private finance and how the different kinds of finance should be accounted for (interview with senior European Commission official, 7 September 2011). The process pressured the finance ministries in question to define their position on climate finance through analysis, that is, a process that influenced their cognitive and normative ideas regarding climate finance. The different elements of those papers were brought together in early drafts of the St Andrews Communiqué. The process also established a common ground on several issues before going into the St Andrews meeting in early November 2009 although this did not translate into an actual agreement on climate finance including commitments (interview with senior European Commission official, 7 September 2011).

The first draft from St Andrews contained several provisions that were quite farreaching at the time given that climate finance negotiations had come to a halt in the UNFCCC negotiations, and would have constituted important regulatory output if adopted. Firstly, regarding the generation of finance, it contained the first mention of the commitment of developed countries to the USD 100 billion target - part of the Copenhagen Accord agreed a few weeks later at COP15 (interview with senior European Commission official, 7 September 2011) as well as the recognition of the different sources (including private and carbon market sources), which remained in the final St Andrews Communiqué (G20, 2009; G20 Finance Ministers and Central Bank Governors, 2009). These provisions can be compared to the UNFCCC

\footnotetext{
${ }^{1}$ Although the G20 finance ministers and central bank governors meet together, within this forum finance ministers and ministries have been more involved in climate finance discussions than central bank governors and central banks.
} 
negotiation text that was discussed at that time, which contained numbers in sharp brackets ranging from the unspecified to 5.5 per cent of developed countries' GDP ${ }^{2}$, and sources ranging from purely public to a combination of public, private and carbon market resources (UNFCCC, 2009b). Thus, the 100 billion target was a rejection of the demand of most UNFCCC negotiators from developing countries that only public financing should count against the target, but it also meant that finance ministries in developed countries accepted the climate finance target (an idea which many of them initially opposed).

Second, the Communiqué emphasised efficiency, an approach that was more widespread among developed than developing countries but resonated better among finance ministers from developing countries than UNFCCC negotiators from the same countries. In this way, the first aspect of economisation (placing climate finance on the agenda of an economic institution) led to the second aspect of economisation (an economic framing of climate finance).

Yet, at the St Andrews meeting, the ministers were unable to agree on the draft joint statement on the table because of the United States insisting that the World Bank should be the trustee of the Green Climate Fund, and China and India opposing this (interview with senior UK Treasury official, 30 June 2011). China also insisted on references to Common but Differentiated Responsibilities and Respective Capabilities (CBDR) which made a compromise more difficult to achieve (interview with senior UK Treasury official, 30 June 2011). Thus, CBDR was much more controversial than efficiency. As a consequence of these disagreements, the climate finance provisions of the official Communique of the meeting did not contain any significant commitments or agreements on disputed issues (Vorobyova and Willard, 2009).

Following 2009, climate finance continued to be addressed by experts under the G20 finance ministers and central bank governors, and these meetings became institutionalised with the establishment of the G20 Climate Finance Study Group (until 2013 named the Study Group on Climate Finance) during the 2012 Mexican Presidency (G20 Heads of State and Government, 2012). The Climate Finance Study Group reported to G20 Leaders on how to mobilise climate finance to meet the USD 100 billion target for climate finance agreed at COP15. The Study Group was discontinued after 2016, with the Green Finance Study Group (in 2018 renamed the Sustainable Finance Study Group) continuing some of its efforts and addressing environmental and sustainable finance from a perspective mainly focusing on private finance (Hansen et al., 2017). These discussions were rather technical, and although the G20 finance ministers and central bank governors discussed climate finance provisions in a Paris Agreement in the run-up to the Twenty-first

\footnotetext{
${ }^{2}$ G77 and China as a group demanded $0.5-1$ per cent of the GDP of developed countries.
} 
Conference of the Parties to the UNFCCC (COP21), the level of ambition for G20 involvement was much lower than at St Andrews (IISD, 2015a, 2015b). ${ }^{3}$ The G20 expert groups stand out from other climate finance expert groups in terms of mainly reporting to finance ministers and because their members come predominantly from finance ministries (in the case of the Green/Sustainable Finance Study Group also central banks). While finance ministries had discussed climate change in several forums, the G20 was the forum in which this involvement was most institutionalised.

G20 study groups are seldom permanent fixtures and can be discontinued after a period of time, depending on the priorities and preferences of each new incoming Presidency (interview with former chair of G20 Study Group, 30 April 2020) or if the work set out in the Terms of Reference have been completed. The purpose of both post-2009 working groups was to provide knowledge aimed at forming the basis for discussions, rather than significant commitments similar to those the G20 aimed to provide at St Andrews. The Climate Finance Study Group was tasked with considering 'ways to effectively mobilize resources taking into account the objectives, provisions and principles of the UNFCCC' (G20 Heads of State and Government, 2012, para. 71).

More specifically, in 2011, the G20 finance ministers and central bank governors had requested a report on the mobilisation of climate finance from a group of International Organisations (IOs) led by the World Bank and including the IMF and the OECD (discussed in detail in Chapters 11 and 12). This report provided a basis for subsequent discussions in the Climate Finance Study Group. In 2012 and 2013, the Climate Finance Study Group delivered reports on focusing on the mobilisation of climate finance, and defining the issue in terms of meeting the USD 100 billion target without specifying any kind of burden-sharing, except that the funds should be mobilised by developed countries (G20 Climate Finance Study Group, 2012, 2013). In this way, it was up to the individual countries to decide how much public climate finance they wanted to provide, reflecting an approach to climate finance that was very much driven by individual national decisions. In terms of the question of what kind of finance counts as climate finance, private climate funding was framed as constituting an important source of climate finance, and carbon pricing policies were highlighted as a potential source of climate finance but also one which it was up to the individual state to decide whether it wanted to adopt. Carbon pricing was recommended with reference to its efficiency (G20 Climate Finance Study Group, 2012, 2013). Linking climate finance to carbon pricing is an ideal-typical case of economisation, since it links climate finance with the instrument for

\footnotetext{
${ }^{3}$ The Paris Agreement provisions on climate finance were also rather modest compared to progress made in other areas.
} 
addressing climate change favoured by most mainstream economists (see also discussion of carbon pricing in Chapter 1 and 7).

After 2013, other issues than mobilising climate finance were included on the agenda, such as improving adaptation finance and collaboration between climate funds as well as leveraging private finance (G20 Climate Finance Study Group, 2014, 2015, 2016a). These issues were treated as being as important as the mobilisation of climate finance and reflected an emphasis on the efficiency of the climate finance mobilised. The approach to these issues was rather technical and avoided references to equity-oriented norms such as CBDR except for generic references to respecting the 'principles, provisions and objectives' of the UNFCCC (G20 Climate Finance Study Group, 2015). The stated objectives of the Study Groups' reports were to share experiences and best practices, reflecting a countrydriven approach in which it was up to the individual state to choose the approach that best suited its national circumstances and preferences.

Adaptation finance was addressed in the 2014 and 2015 reports with an emphasis on removing barriers to effective adaptation finance (G20 Climate Finance Study Group, 2014, 2015, 2016a). In general, the importance of private finance and development aid to climate finance was emphasised, as was the use of financial instruments to mobilise climate finance, leverage private finance and reduce investment and climate risks. This emphasis reflects the G20's character as a forum for economic policy. The G20 experts did not (either before or after 2013) provide output explicitly addressing the issue of what constitutes climate finance, but only underscored the importance of tracking climate finance. The 2012 and 2014 reports underscored the divergence of opinions among the member states, particularly regarding the role of public finance vis-à-vis private finance and development aid, including whether public finance should be new and additional to Official Development Assistance (ODA; G20 Climate Finance Study Group, 2012, 2014). Particularly China and India stressed the importance of public finance and additionality as well as of private finance not undermining Annex II countries' obligation to provide public climate finance (G20 Climate Finance Study Group, 2012, 2014). On the other hand, developed countries focused more on leveraging private finance and improving efficiency.

The Green/Sustainable Finance Study Group had the broader purpose of exploring how to scale up green financing, understood as the 'financing of investments that provide environmental benefits in the broader context of environmentally sustainable development' (G20 Green Finance Study Group, 2016), p. 5) Consequently, it did not focus on the USD 100 billion target or other contested issues during the UNFCCC negotiations, but rather on private finance and issues such as greening the banking system, the bond market and institutional investors, as 
well as the role of risk and sustainable private equity and venture capital (G20 Green Finance Study Group, 2016, 2017; G20 Sustainable Finance Study Group, 2018). As such, it adopted an economic framing of sustainability, but one which was less focused on externalities and more on overcoming barriers to green investment such as risks. Arguably, this approach was less about textbook environmental economics targeting the nature of the problem (an externality), and more about providing economic, financial solutions to the problem. Furthermore, the focus on sustainability meant that climate change was no longer the only environmental issue addressed, although it still took up considerable space.

\subsection{Causes}

Regarding the first aspect of economisation, in 2009, the member states and especially the UK Presidency played an important role in ensuring that climate finance was included on the agenda, thus intentionally economising the issue. The entrepreneurship of the UK Presidency was important in shaping the level of G20 efforts regarding climate finance (interview with former senior UK Treasury official, 30 June 2011), and subsequent Presidencies were also influential in shaping the activities of the study groups, for example, the 2012 Mexican Presidency establishing the Climate Finance Study Group and the 2016 Chinese Presidency establishing the Green Finance Study Group. Later Presidencies have been less ambitious in their entrepreneurial roles than the UK, as the deadlock in St Andrews killed off the idea that the G20 could be a major game changer as regards climate finance.

In 2009, there was a general agreement among the finance ministers that the G20 could influence the UNFCCC climate finance negotiations by establishing a common understanding and agreement among the G20 members, who represent the majority of the most important states in the UNFCCC process. The membership circle was also important when the G20 was not able to reach an agreement on the more far-reaching provisions of the draft of the St Andrews Communique due to differences between the United States and China (and to a large degree India) regarding World Bank trusteeship of the Green Climate Fund and CBDR. Similar divisions between, on the one hand, China and India and, on the other, developed countries also characterised early discussions of tracking climate finance in the Climate Finance Study Group. These disagreements demonstrate the limits of the influence of economisation: it was impossible to overcome the deep-rooted differences between, on the one hand, China and India and, on the other, developed countries, the United States in particular. In the Green/Sustainable Finance Study Group these divisions were less pronounced as the Study Group was asked to look 
at mobilising private capital unlike in the climate finance groups that were focused on public sector transfers related to the UNFCCC negotiations (interview with former chair of G20 Study Group, 30 April 2020).

Furthermore, regarding the membership circle, the G20 does not include lower-income countries. Nonetheless, the G20 have addressed the issue of adaptation finance, which is primarily a concern of lower-income countries since they are the main per capita recipients of such finance, while the emerging economies are the main recipients of mitigation finance (Halimanjaya, 2015; Weiler et al., 2018). In conclusion, while the membership circle mattered especially in terms of limiting how far the G20 was able to go, it cannot explain neither the emphasis on adaptation finance nor on efficiency and economic framings in G20 output compared to the positions of the G20 members in the UNFCCC.

A major factor in the way in which the G20 has addressed climate finance (the second aspect of economisation) has been its economic worldview. This worldview is evident in the general emphasis on efficiency, and the specific emphasis on the importance of private finance and development aid to climate finance, and on the use of financial instruments to mobilise climate finance, leverage private finance and reduce investment and climate risks. Climate finance is economised by treating it as an economic issue to be addressed with financial instruments (leverage, de-risking). While these trends are also evident in the climate finance output from other institutions, e.g. the UNFCCC Standing Committee on Finance $(2016,2018)$, the G20 has to a larger degree singled them out as key issues. In this respect, the fact that most representatives of member states come from finance ministries or central banks has been an important aspect of this worldview.

Regarding the interaction with other institutions, the UNFCCC in particular played an important role. Not only was the G20 involvement in climate finance driven by the desire to influence the UNFCCC negotiations, but norms from the UNFCCC also shaped the discussions within the G20, most notably the controversy over references to CBDR. The relationship between the G20 and the UNFCCC gradually became more synergistic, going from the $\mathrm{G} 20$ being seen as an alternative forum to the UNFCCC for key climate finance discussions to the G20 study groups providing knowledge about how to meet UNFCCC obligations, although with a clear economic framing. The more synergistic relationship between the two institutions should also be seen in the light of the UNFCCC, especially the Standing Committee on Finance (SCF), moving in a more technical direction and leaving more discretion to the states. The move to more technical discussions in both institutions also reflects that with the adoption of the USD 100 billion target, 
the most important political decision had been reached, and the remaining topics were more technical. As mentioned earlier, as the G20 output became less focused on the UNFCCC's USD 100 billion target with the Green/Sustainable Finance Group taking over, divisions among member states became less salient. This shows that (cognitive and normative) interaction with the UNFCCC regarding what counts towards the USD 100 billion target meant that divisions over this issue spilled over from the UNFCCC to the G20, although it was ameliorated by the economic worldview of the institution.

Besides the UNFCCC, the Climate Finance Study Group interacted continuously with other institutions, particularly development banks, the OECD and the Global Environment Facility and the think tank the Climate Policy Initiative, which were tasked with providing reports and other input to the Study Group (G20 Climate Finance Study Group, 2015, 2016b). This technical and cognitive input provided the basis for parts of the Study Group's report.

\subsection{Consequences}

\subsubsection{International Consequences}

\section{The UNFCCC}

The international institution most influenced by the G20's climate finance output is arguably the UNFCCC, at least as regards the Copenhagen Accord negotiations. Although the finance ministers were not able to reach a final agreement on climate finance in St Andrews, they were ready to agree on several issues which would later be found in the Accord (interview with senior European Commission official, 7 September 2011). When comparing the climate finance provisions of the St Andrews Communiqué (and particularly earlier drafts of this Communiqué) and the Copenhagen Accord, crucial similarities between the St Andrews Communiqué and the Accord stand out, as discussed in Section 10.1. Agreements (or in this case, a nearly completed agreement) in one institution affecting the possibilities for agreement in another constitute an incentive-based and cognitive influence (see also Chapter 2). Incentive-based because states would be more inclined to offer to change their negotiation positions within the UNFCCC if they knew - on the basis of the G20 negotiations - that the other states were likely to respond to such offers with similar offers. Cognitive because the G20 process established an understanding among the finance ministers of both developing and developed countries, which influenced how climate finance was addressed in the UNFCCC (interview with senior Indian Finance Ministry official, 3 November 2014). This understanding was developed in the meetings of experts and is visible in the way in which the provisions on the governance of climate finance reflect finance ministerial thinking. 
The G20 process meant that the finance ministries of the G20 developed countries accepted this obligation, including the obligation to fund adaptation, which runs counter to traditional finance ministerial preferences for mitigation finance, which provides a global public good (Pickering et al., 2015b). In this respect, it is important to note that the 'Circle of Commitment' that negotiated the Accord essentially consisted of the G20 minus a few middle-income countries such as Turkey and Argentina but plus representatives of country groups such as the Alliance of Small Island States and a few smaller countries. The importance of the influence of the G20 is also evident in the similarities between the Copenhagen Accord and the St Andrews text, especially when compared to how the Copenhagen Accord and the UNFCCC negotiation text differ (UNFCCC, 2009a, 2009b).

After 2009, the G20 output has not only been more modest in its ambitions, but its influence on the UNFCCC is also harder to discern. The G20 finance ministers (and central bank governors) have only had a limited involvement in the G20 discussions of climate finance, and the state leaders have been less directly involved in the UNFCCC negotiations compared to in 2009. Thus, the direct link between the two institutions at the level of highly powerful government officials has ceased to exist, and while the technical experts participating in the Climate Finance Study Group may influence their country's position during the UNFCCC negotiations, this influence is much more indirect. Another factor is that the USD 100 billion target - despite the uncertainty regarding how it can be met - has been the most important climate finance commitment in the past twenty years. Once it was decided, there was less scope for the involvement of the political level. That meant that a key strength of the G20, its ability to agree on disputed but common political issues among twenty of the most powerful states, was less salient. The experts in the G20 Climate Finance Study Group with their economic approach differed less than the experts in the UNFCCC Standing Committee on Finance. They were influenced by and part of the same trend of framing climate finance in economic terms of leveraging private finance and mainstreaming climate concerns into development aid.

\section{Institutions Tasked with Providing Analysis}

Another set of institutions influenced by the G20 output has been the institutions tasked with providing analysis to the G20 Study Groups. Unsurprisingly, given that it often acts as an unofficial G20 Secretariat, the OECD has provided many of these reports, but nonetheless these reports constitute a relatively small proportion of the overall OECD publications on climate finance (see Chapter 11). The OECD reports provided to the G20 also stressed the same issues and adopted similar framings to the other OECD publications on climate finance, and did not increase in volume 
after the G20 requests (see Chapter 11). Thus, the G20 hardly induced a fundamental change to the way in which the OECD addressed the issue or the OECD agenda. The same applies to another major provider of reports, namely the World Bank, which also provided a range of publications on climate finance beyond those delivered to the G20. Again, the non-G20 World Bank output is rather similar in approach and theme to the publications delivered to the G20 (see e.g. World Bank, 2010, 2013a, 2017, 2018, 2020c). Other multilateral development banks (MDBs), particularly the Inter-American Development Bank, have also contributed to the reports to the G20, although to a much lesser degree than the World Bank (G20 Climate Finance Study Group, 2015). UN institutions, particularly the Secretariats of both the Green Climate Fund and the Global Environment Facility, and the UNEP and UNDP, also contributed to reports to the G20, again without these reports being radically different to other publications on climate finance published by these institutions (Robbins, 2017; UNDP, 2012). Largely, the reports published by these UN institutions (both those provided to the G20 and the rest) are part of the wider trend of focusing on greening finance and investment rather than the provision of public climate finance.

All of these institutions were used to addressing climate finance, in a knowledgeproducing role and/or as providers or implementers of climate finance. Arguably, the G20 commitment exerted its greatest influence over the IMF, the Bank of International Settlements and the Financial Stability Board, which were less used to addressing climate finance, and which provided reports and other input on green and sustainable financial issues such as carbon pricing and green bonds (G20 Green Finance Study Group, 2016, G20 Sustainable Finance Study Group, 2018, IMF, 2011a, 2011b). In the case of the IMF, the output addressing climate finance even decreased significantly when it no longer reported to the G20, demonstrating the G20's influence on the IMF agenda (see Chapter 12).

\subsubsection{Domestic Consequences}

The arguably most important influence of the G20 on climate finance at the domestic level has been its contribution to a climate finance system in which the most important decisions are left to the developed countries providing climate finance (Pickering et al., 2017). As I have argued earlier, the G20 has contributed to this system via its influence over the Copenhagen Accord provisions on climate finance, a cornerstone of this system. The G20 Climate Finance Study Group also became a part of this system. The factors shaping the domestic decisions regarding the allocation of climate finance mainly consist of domestic factors (Halimanjaya, 2015, 2016; Michaelowa and Michaelowa, 2011b; Peterson and 
Skovgaard, 2019; Pickering et al., 2015b). International influences, including from the G20 (or even from the UNFCCC), have had limited direct impact. The G20 Climate Finance Study Group has worked as an important forum for learning about and developing cognitive ideas about climate finance, especially in the early years, when it was a topic that was new to experts in the Study Group (interview with senior European Commission official, 7 September 2011). In this respect, it is important to note that the G20 Climate Finance Study Group was the main institutionalised forum for finance ministry officials discussing climate finance. The EU had a similar working group also oriented towards developing the EU position in the negotiations, but which covered a much smaller share of the global population and climate finance.

In the case of climate finance, international institutions can shape two aspects of a country's climate finance policy, namely its position in the climate finance negotiations and its provision of climate finance (in the case of developed countries) and the implementation of climate finance (in the case of developing countries) respectively. The involvement of finance ministries is generally lower than the involvement of environment and development ministries both as regards developing a country's position in the UNFCCC negotiations (Skovgaard, 2017b; Skovgaard and Gallant, 2015) and the provision of climate finance (Peterson and Skovgaard, 2019; Pickering et al., 2015), although in both cases it varies considerably from country to country. Yet, while they are less directly involved, finance ministries still hold considerable power over climate finance in all countries, particularly as regards their ability to cut funds for climate finance if it is not spent in a way that they approve of. Thus, involving finance ministry officials in G20 discussions may change the officials' understanding of climate finance, and potentially lead them to accepting climate finance in a way they otherwise would not have done, but also to encouraging their direct involvement in climate finance to shape it to ensure that it matches their worldview.

Yet, existing research does not suggest that G20 member states are more likely to involve finance ministries in either the UNFCCC negotiations or the policy processes determining the allocation of climate finance (Peterson and Skovgaard, 2019; Skovgaard and Gallant, 2015). Thus, there is no overall indication that there is a spill-over from the involvement of G20 finance ministries in G20 climate finance discussions to them becoming more involved in other climate finance policy processes.

It is possible to identify influences from the G20 through the pathways of cognitive and normative change and changes to incentive-based and public and policymaking agendas by examining the five countries studied here in greater detail (see also Chapter 2). 
In the case of the United States, the different aspects of climate finance have predominantly been shaped by party politics. The US position in all climate negotiations including those concerning climate finance changed radically with the change of Presidents. While the Obama administration was a hardliner in the climate finance negotiations in terms of opposition to finance targets and relinquishing control over allocation, the Trump administration's decision to leave the Paris Agreement and opposition to the GCF means it plays no role in climate finance negotiations (Bowman and Minas, 2019; Skovgaard, 2017b). Perhaps surprisingly, the provision of climate finance has been less affected, with levels under Trump about a quarter below 2016 levels, although the lack of transparency makes it difficult to determine the exact amounts and their allocation (Thwaites, 2019). Importantly, the United States constitutes an example of a country with a high degree of involvement of the Treasury, inter alia because it has the responsibility of financing flows to multilateral funds, including the GCF and the Climate Investment Funds (Pickering et al., 2015b). The US Treasury under Obama saw the G20 as a forum for climate discussions that was important in its own right and significant for addressing climate change in economic terms (Lew, 2014). Later, the Trump administration has been more sceptical of any kinds of climate discussions in the G20. Yet, even to US Treasury officials during the Obama administration it was not the only relevant forum for discussions with other finance ministry officials, as forums such as the Major Economies Forum and World Bank meetings as well as informal discussions were also important (interview with former US Treasury official, 8 April 2014). Thus, while participation in such meetings were important for cognitive influences in the shape of US officials gradually developing their understanding of climate finance issues, it is difficult to disentangle the influence from the G20 from that of other forums (interview with former US Treasury official, 8 April 2014). In terms of the US public agenda (see Table 10.1), the G20 influence was limited and the

Table 10.1 Climate finance and the G20 in the US media: New York Times and Washington Post

\begin{tabular}{|c|c|c|c|c|c|c|c|c|c|c|c|c|}
\hline & 2009 & 2010 & 2011 & 2012 & 2013 & 2014 & 2015 & 2016 & 2017 & 2018 & 2019 & Total \\
\hline $\begin{array}{l}\text { Articles referring to } \\
\text { US climate } \\
\text { finance and } \\
\text { the G20 }\end{array}$ & 2 & 0 & 0 & 0 & 0 & 0 & 0 & 0 & 0 & 0 & 0 & 2 \\
\hline $\begin{array}{l}\text { All articles referring } \\
\text { to climate finance } \\
\text { (international and } \\
\text { domestic) }\end{array}$ & 5 & 5 & 4 & 1 & 3 & 1 & 12 & 1 & 3 & 6 & 5 & 46 \\
\hline
\end{tabular}


institution's output on climate finance was only addressed in articles in the New York Times and Washington Post in 2009, in both cases focusing on how climate finance was not a major issue at the Pittsburgh Summit (Eilperin, 2009a; Galbraith, 2009).

The United Kingdom has consistently had a high profile both regarding the climate finance negotiations and the delivery of climate finance (Skovgaard, 2015). The UK is one of the few countries that meets the 0.7 per cent Gross National Income (GNI) target for ODA, and is among the top five global contributors (Atteridge et al., 2019). The United Kingdom has also sought to establish a common ground and promote action on climate finance in various UN and non-UN institutions, including the G20. Most notably, the UK government took on an important entrepreneurial role in establishing the 2009 climate finance expert group and as the host of the St Andrews meeting. At a later stage, the Bank of England, representing the UK government co-chaired the Green/Sustainable Finance Study Group, reflecting Bank Governor Mark Carney's strong interest in the relationship between climate change and risk within the global financial system (interview with former chair of G20 Study Group, 30 April 2020). Thus, both the UK Treasury and the Bank of England have interacted with the G20. Similarly to the United States, participation in the G20 study groups influenced cognitive ideas in these two domestic institutions regarding climate finance issues, but this influence was limited by the UK government (especially the Bank of England at the time of the Green/ Sustainable Finance Study Group) already having established an understanding of these issues when entering the G20 discussions. Notably, in spite of the relatively prominent place that climate finance has enjoyed on the UK public agenda (see Table 10.2), only two articles have linked the UK's status as a G20 country to climate finance, in both cases noting the UK government's

Table 10.2 Climate finance and the G20 in the UK media: The Guardian and The Independent

\begin{tabular}{|c|c|c|c|c|c|c|c|c|c|c|c|c|}
\hline & 2009 & 2010 & 2011 & 2012 & 2013 & 2014 & 2015 & 2016 & 2017 & 2018 & 2019 & Total \\
\hline $\begin{array}{l}\text { Articles referring to } \\
\text { UK climate } \\
\text { finance and } \\
\text { the G20 }\end{array}$ & 0 & 0 & 0 & 0 & 0 & 2 & 0 & 0 & 0 & 0 & 0 & 2 \\
\hline $\begin{array}{l}\text { All articles referring } \\
\text { to climate finance } \\
\text { (international and } \\
\text { domestic) }\end{array}$ & 20 & 22 & 6 & 1 & 2 & 7 & 33 & 3 & 2 & 2 & 2 & 100 \\
\hline
\end{tabular}


reluctance to provide (new) finance to the Green Climate Fund (Carrington and Watt, 2014; Vidal, 2014a).

India was the largest recipient of public climate finance in the period 2002-17, having received about USD 22 billion in climate finance ${ }^{4}$ (Atteridge et al., 2019). In the climate finance negotiations, India has adopted a stance stressing historical responsibility, CBDR, developed country targets for public climate finance and channelling climate finance through UNFCCC institutions (Dasgupta and Climate Finance Unit, 2015; Skovgaard, 2017b). The Indian Ministry of Finance has had the lead on climate finance since 2011, when a designated Climate Finance Unit was set up within the Ministry (and also leads participation in the G20). The Ministry of Finance frames climate change as an issue of equity but also of efficiency. The former is more important, since according to the Ministry, the developed countries delivering on their (equity-based) climate finance is a precondition for allocating climate finance in an efficient manner. The emphasis on CBDR has characterised the Indian position in the climate negotiations generally speaking (Sengupta, 2019; Thaker and Leiserowitz, 2014) and is shared with other involved ministries such as the Ministry of the Environment. Regarding the G20, the Ministry of Finance is of the opinion that any decisions on climate issues need to be adopted within the UNFCCC, and the G20 is mainly a forum for economic issues (interview with senior Indian Ministry of Finance official, 3 November 2014). Nonetheless, the Ministry of Finance sees the G20 as an important forum for discussion and sharing best practices and technical knowledge, which may help clarifying and creating a shared understanding among twenty powerful countries, an understanding that may make it easier to reach agreements in the UNFCCC (interview with senior Indian Ministry of Finance official, 3 November 2014). Thus, participation in G20 expert groups has led to cognitive changes in the Ministry, affecting the negotiation position in the

Table 10.3 Climate finance and the G20 in Indian media: The Hindu and Times of India

\begin{tabular}{llllllllllllll}
\hline \hline & 2009 & 2010 & 2011 & 2012 & 2013 & 2014 & 2015 & 2016 & 2017 & 2018 & 2019 & Total \\
\hline $\begin{array}{l}\text { Articles referring to } \\
\text { climate finance in } \\
\text { an Indian context }\end{array}$ & 0 & 0 & 0 & 0 & 0 & 7 & 1 & 2 & 0 & 0 & $\mathbf{1 0}$ \\
$\begin{array}{l}\text { and the G20 } \\
\text { All articles referring } \\
\text { to climate finance } \\
\text { (international and } \\
\text { domestic) }\end{array}$ & 2 & 1 & 4 & 1 & 5 & 47 & 14 & 3 & 14 & 14 & $\mathbf{1 0 2}$ \\
\hline \hline
\end{tabular}

${ }^{4}$ Understood as bilateral and multilateral finance with a principal climate mitigation or adaptation objective. 
Table 10.4 Climate finance and the G20 in the Danish media: Politiken and Jyllands-Posten

\begin{tabular}{|c|c|c|c|c|c|c|c|c|c|c|c|c|}
\hline & 2009 & 2010 & 2011 & 2012 & 2013 & 2014 & 2015 & 2016 & 2017 & 2018 & 2019 & Total \\
\hline $\begin{array}{l}\text { Articles referring to } \\
\text { Danish climate } \\
\text { finance and } \\
\text { the G20 }\end{array}$ & 0 & 0 & 0 & 1 & 0 & 0 & 0 & 0 & 0 & 0 & 0 & 1 \\
\hline $\begin{array}{l}\text { All articles referring } \\
\text { to climate finance } \\
\text { (international and } \\
\text { domestic) }\end{array}$ & 0 & 1 & 4 & 61 & 28 & 45 & 18 & 19 & 48 & 60 & 26 & 310 \\
\hline
\end{tabular}

UNFCCC, but also how the Ministry perceives the implementation of climate finance projects in India.

On the public agenda, the link between the G20 and climate finance existed only in the run-up and aftermath of COP21. Perhaps surprisingly, the rather modest climate finance discussions during the 2015 Turkish Presidency received most attention (Mohan, 2015c).

As regards Indonesia ${ }^{\mathbf{5}}$, the country was the second-largest recipient of climate finance in the period 2002-17, having received USD 9.7 billion in climate finance during this period (Atteridge et al., 2019). During the climate finance negotiations, Indonesia has generally adopted a less hardline position than India. While it has stressed CBDR, developed countries' climate finance targets and the role of the UNFCCC, it has been more positive regarding non-UNFCCC channels for climate finance and has contributed to the GCF, thus contributing to the softening of the developed/developing country distinction (Skovgaard, 2017b). The Indonesian Ministry of Finance has been involved in the implementation of recommendations from climate finance negotiations without taking the lead on either of these two issues. In terms of the overarching framing of climate finance, the Indonesian Ministry of Finance has emphasised efficiency, signalling Indonesian readiness for climate friendly investment to the market, carbon pricing as well as CBDR (Indonesian Ministry of Finance, 2009; interview with a senior Indonesian Finance Ministry official, 24 June 2015). The Ministry's responsibility for G20 has together with the 2007 COP13 in Bali - increased its attention to climate change. In the G20 expert groups, the Indonesian Ministry of Finance officials have stressed efficiency over CBDR (G20 Climate Finance Study Group, 2014).

As a non-G20 country, Denmark is less relevant when studying direct influences. As regards the public agenda, a couple of articles addressed Prime Minister

\footnotetext{
${ }^{5}$ A media analysis of the Indonesian media coverage of the term climate finance has not been carried out.
} 
Lars Løkke Rasmussen giving a presentation at the St Andrews meeting, and focused inter alia on the fiscal costs of climate finance to Denmark (Beder and Plougsgaard, 2009; Kongstad et al., 2009).

\subsection{Summary}

The case of the G20 addressing climate finance demonstrates both the potential of economisation and its limitations. On the one hand, it constitutes a clear-cut case of an economic institution framing a climate issue in economic terms that differed from how the non-economic institution (the UNFCCC) had framed it. This is evident in the emphasis on efficiency, reducing costs, leveraging private finance and other economic instruments. On the other hand, this economisation had a limited influence: the St Andrews meeting failed to overcome the fundamental fault lines between developed and developing countries, although it did create consensus on key issues that later appeared in the Copenhagen Accord. After 2009, its less ambitious knowledge output had an impact on a set of international institutions (mainly in terms of moving climate finance up their agendas) and domestically (mainly in terms of influencing cognitive ideas). More recently, the G20 interest in climate finance has been replaced by an interest in sustainable (private) finance, underscoring that economisation does not entail one given set of output. Interaction with other institutions, particularly the desire to influence the UNFCCC, was a major factor in inducing the G20 to address climate finance, as was entrepreneurship from the Mexican and especially UK Presidencies. The institutional worldview, interaction with other (mainly economic) institutions and to some degree also the membership circle have shaped the G20's economic approach to climate finance. 